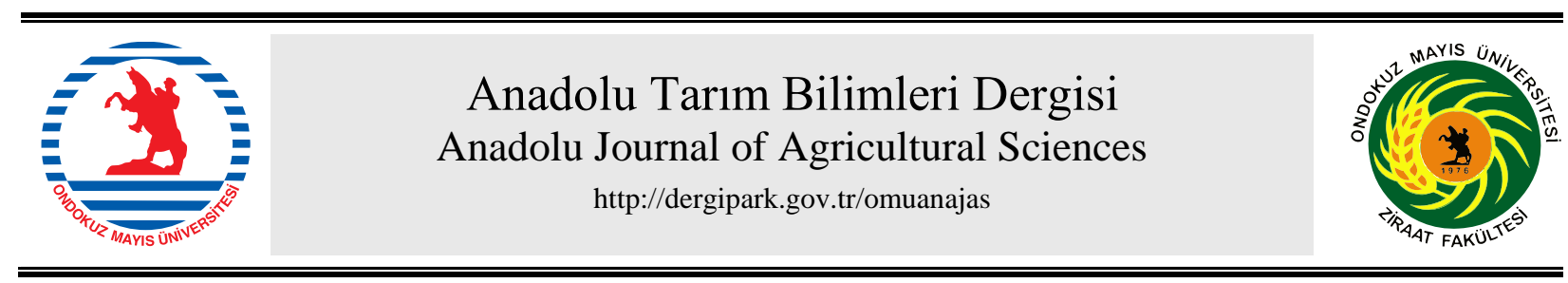

Araştırma/Research

Anadolu Tarım Bilim. Derg./Anadolu J Agr Sci, 35 (2020) ISSN: 1308-8750 (Print) 1308-8769 (Online) doi: 10.7161/omuanajas.697731

\title{
Samsun ilinde biber alanlarında enfeksiyon oluşturan Potato virus Y patotiplerinin belirlenmesi ve moleküler karakterizasyonu ๑İlyas Deligöz ${ }^{\mathrm{a}^{*}}$, Miray Arlı Sökmen ${ }^{\mathrm{b}}$
}

\author{
${ }^{a}$ Karadeniz Tarımsal Araştırma Enstitüsü, Bitki Sağlığı Bölümü, Samsun, Türkiye \\ ${ }^{b}$ Ondokuzmayls Üniversitesi, Ziraat Fakültesi, Bitki Koruma Bölümü, Samsun, Türkiye
}

*Sorumlu yazar/corresponding author: ilyasdeligoz@yahoo.com

Geliş/Received 09/03/2020 Kabul/Accepted 14/09/2020

\begin{abstract}
ÖZET
Potato virus $Y$ (PVY), biberde en fazla zarar oluşturan virüs türleri arasında yer almaktadır. PVY biber izolatları, pvr2- eIF4E lokusundaki, $p v r 2^{1}$ ve $p v r 2^{2}$ dayanıklılık genlerine sahip biber genotiplerinin verdikleri reaksiyonlara göre üç ayrı patotip altında sınıflandırılmaktadır. Bu çalışmada, Samsun ilinde biberde enfeksiyon oluşturan PVY patotiplerinin belirlenmesi amaciyla 2010 ve 2011 yıllarında toplam 1012 yaprak örneği toplanmış ve daha sonra örnekler, PVY'ye spesifik poliklonal antiserum kullanılarak DAS-ELISA yöntemi ile test edilmiştir. Test sonucunda, 2010 yılında alınan örneklerin \%11.9'unun, 2011 yılında ise \%5.8'inin PVY ile enfekteli olduğu belirlenmiştir. Çoğaltımı sağlanan 13 PVY izolatı, patotip ayrım setindeki bitkilere inokule edilmiştir. Bu bitkilerin reaksiyonlarına ve ELISA sonuçlarına göre izolatların 9'nun Patotip 0 (PVY-0)'a, 4'ünün ise Patotip 1 (PVY-1)'e ait olduğu saptanmıştır. Ayrıca PVY-0 ve PVY-1 patotiplerine ait ikişer izolatın kılıf protein (CP) gen bölgesinin nükleotid dizileri elde edilmiştir. Nükleotid BLAST analizi, PVY-0 patotipine ait SÇ-9 izolatı ve PVY1 patotipine ait SÇ-84 ve SÇ-87 nolu izolatların, Türkiye orjinli Tu12.3 biber izolatı ve İspanya orjinli LYE 84.2 domates izolatı ile genetik benzerlik (\% 97-98) gösterdiğini; PVY-0 patotipine ait SB-63 nolu izolatın ise ABD ve Polonya'da patateste belirlenen NTN ırkına ait izolatlar ile \% 99 benzer olduğunu ortaya koymuştur. Ayrıca uygulanan filogenetik analiz, SÇ-9, SÇ-84 ve SÇ-87 izolatlarının PVY'nin C grup izolatları ile, SB-63 izolatının ise $\mathrm{N}$ grubundaki izolatlar ile aynı grupta kümelendiğini göstermiştir.
\end{abstract}

Determination and molecular characterization of pathotypes of Potato virus $Y$ infecting pepper in Samsun province, Turkey

\section{ABSTRACT}

Potato virus $Y$ (PVY) is one of the most devastating viruses on pepper. Pepper PVY isolates are classified into three pathotypes according to the reactions of pepper genotypes possessing the $p v r 2^{1}$ and $p v r 2^{2}$ resistance genes at the pvr2-elF4e locus. In this study, in order to determine PVY pathotypes infecting pepper in Samsun province, Turkey, a total of 1012 leaf samples were collected in 2010 and 2011, and these samples were tested by DAS-ELISA using virus-specific polyclonal antiserum. The percentages of PVY infections were found to be 11.9\% in 2010 and \%5.8 in 2011. Thirteen PVY isolates were propagated and inoculated to pepper differentials to discriminate the pathotypes of PVY. According to reactions of different pepper genotypes and ELISA, nine isolates were found to belong to pathotype 0 (PVY-0) and four isolates to pathotype 1 (PVY-1). The coat protein (CP) gene nucleotide and predicted amino acid sequences of four PVY isolates were obtained. Nucleotide BLAST analysis showed that SÇ-9 (PVY-0), SÇ-84 (PVY-1) and SÇ-87 (PVY-1) isolates had nucleotide sequence similarity (\% 97-98) with Tu12.3 isolate from pepper in Turkey and LYE 84.2 isolate from tomato in Spain. In contrast, the isolate SB-63 (PVY-0) had the highest nucleotide identity (\% 99) with the isolates belonging to potato NTN strain determined in USA and Poland. Phylogenetic analysis also showed that the pepper isolates SÇ-9, SÇ-84 and SÇ-87 were clustered with the group C isolates of PVY, while the isolate SB-63 was clustered with the group N isolates of PVY.

Keywords: Pepper PVY pathotype

(C) OMU ANAJAS 2020 characterization
Anahtar Sözcükler: Biber PVY patotip karakterizasyon 


\section{Giriş}

Biber, dünyada domates ve hiyardan sonra en fazla üretilen sebzedir. Türkiye, biber üretiminde Çin ve Meksika'dan sonra üçüncü sırada bulunmaktadır (FAO, 2020) Türkiye'de 2019 y1lında 2.625.669 ton biber üretimi elde edilmiştir. Biber üretim bölgelerinin başında Ege, Akdeniz, Marmara ve Karadeniz gelmektedir. Samsun ili Türkiye biber üretiminde 133563 tonluk üretim miktarı ile Antalya (501213 ton), Bursa (188984 ton) ve Manisa (174769 ton) illerinden sonra 4. sirada yer almaktadır (TUIK, 2020).

Potato virus $Y$ (PVY), başta patates, biber, domates ve tütün olmak üzere Solanaceae familyasına ait pek çok üründe tüm dünyada yaygın olarak enfeksiyon oluşturmaktadır (Kerlan, 2006). Mekanik olarak ve yaklaşık 73 yaprak biti türü ile non-persistent yolla taşınabilen virüs (Varveri, 2000), hassas çeşitlerde \% 80'e kadar verim kaybina neden olabilmektedir (Hamalainen ve ark., 1997). Potyviridae familyası ve Potyvirus cinsinin bir üyesi olan ve bu cinse adını veren PVY, yaklaşık $10 \mathrm{~kb}$ büyüklüğünde pozitif özellikte tek sarmal RNA genomuna ve $740 \mathrm{~nm}$ uzunluğunda ve 11 nm çapında esnek çubuk şeklinde partiküllere sahiptir. Viral RNA, tek okuma çerçevesi (Open Reading Frame $=\mathrm{ORF}$ ) ve ayrica $5^{\prime}$ ve $3^{\prime}$ uçlarında translasyon dışı bölgeleri (untranslated region;UTR) içerir. Yaklaşık 2000 adet k1lif (kapsid) protein alt birimi (kapsomer) partikül oluşumunda kullanılır. Pozitif duyarlı tek sarmal genomik RNA, yaklaşık 3062'amino asitlik tek bir poliproteini kodlar (Riechmann ve ark., 1992). Bu protein, 3 proteaz enziminin proteolitik kesimi sonucunda birden fazla peptit bağını koparmasıyla P1 (Protein 1), HC-Pro (yardımcı bileşen-proteinaz), P3 (Protein 3), 6K1 (6 kilodalton protein 1), CI (sitoplazmik inklüzyon), 6K2 (6 kilodalton protein 2), VPg (genom-bağlı viral protein), NIa (nüklear inklüzyon a), NIb-Pol (nüklear inklüzyon b-RNAdependant RNA polimeraz) ve CP (k1lif proteini) olmak üzere toplam 10 adet işlevsel viral proteine dönüşür (Urcuqui-Inchima ve ark., 2001; Grzela ve ark., 2008). İlave olarak, son yıllarda PVY genomunun P3N-PIPO olarak adlandırılan kısa bir ORF daha içerdiği belirlenmiştir (Quenouille ve ark., 2013).

PVY, oldukça karmaşık çok sayıda ırk (strain) çeşitliliğine sahip bir virüs türüdür. Konukçu dizisi, simptom tipi, serolojik özellikleri ve sekans/filogenetik analiz sonuçlarına göre patateste enfeksiyon oluşturan PVY izolatları, ilk olarak O $\left(\mathrm{PVY}^{\mathrm{O}}\right), \mathrm{N}\left(\mathrm{PVY}^{\mathrm{N}}\right)$ ve $\mathrm{C}$ $\left.(\mathrm{PVY})^{\mathrm{C}}\right)$ olmak üzere 3 ana 1 rk grubuna ayrılmıştır (Moury ve ark., 2002; Kerlan ve Moury, 2008). Daha sonra patateste yeni 1 rk grupları $\left(\mathrm{PVY}^{\mathrm{Z}}, \mathrm{PVY}-\mathrm{NA}^{\mathrm{N}}\right.$ gibi) belirlenmiştir (Karasev ve Gray, 2013). Ayrıca bazı PVY izolatları arasındaki rekombinasyon sonucu, yeni rekombinant ırkların oluştuğu bildirilmiştir (Revers ve ark., 1996; Glais ve ark., 2002; Ogawa ve ark., 2008). $\mathrm{Bu}$ rekombinant ırkların çoğunluğu, $\mathrm{N}$ ve $\mathrm{O}$ gruplarına ait PVY izolatlarının rekombinasyonu sonucu oluşmuştur. Bunlardan bazıları, PVY ${ }^{\mathrm{NTN}}$ (Ogawa ve ark., 2008), PVY ${ }^{\mathrm{N}-\mathrm{Wi}_{\mathrm{i}}}$ (Rigotti ve Gugerli, 2007), PVY ${ }^{\mathrm{NTN}-\mathrm{NW}}$ (Chikh Ali ve ark., 2010) ve PVY $\mathrm{P}^{\mathrm{N}: \mathrm{O}}$ (Karasev ve Gray, 2013) olarak adlandırılmıştır. Bunların dışında, orijini bilinmeyen PVY genomu ile diğer bazı bilinen PVY genomları arasındaki rekombinasyon sonucu oluşan bazı izolatların (PVYNE11, PVY ${ }^{\mathrm{E}}$ ) da bulunduğu rapor edilmiştir (Karasev ve Gray, 2013).

$\mathrm{PVY}^{\mathrm{C}}$ grubu izolatların homojen bir patotip olmasına karşın, farklı iki genetik ırktan oluştukları, $\mathrm{PVY}^{\mathrm{C} 1}$ alt grubunun biberi enfekte edebildiği, $\mathrm{PVY}^{\mathrm{C} 2}$ alt grubunun ise biberi enfekte edemediği bildirilmiştir (Blanco-Urgoiti ve ark., 1998). Biberde enfeksiyon oluşturan PVY patotipleri serolojik olarak birbirileri ile yakın ilişkili olup, antijenik özelliklere dayanan yöntemlerle bu patotipleri ayırmak nadiren mümkün olmaktadır (Gugerli ve Fries, 1983; Jordan ve Hammond, 1991). CP dizi analizi ve monoklonal antibadi (Mab)'ler PVY'nin biber izolatlarını diğer konukçu bitkilerin ırklarından ayırt edilmesinde kullanılabilmesine karşın, PVY'nin biber ırklarını kendi arasında ayırmada başarısız olmaktadır. Patateste PVY'nin ırkları moleküler olarak Ters Transkripsiyon Polimeraz Zincir Reaksiyonu (RT-PCR) metodu ile birbirinden ayrilabilirken (Rigotti ve Gugerli, 2007), biber izolatları ayrılamamaktadır (Llave ve ark., 1999). Biberde PVY patotiplerini ayırma ve sinıflandırma üzerine pek çok çalışma yapılmıştır. Gebre-Selassie ve ark. (1985) tarafindan önerilen sistem günümüzde PVY'nin biber izolatlarını patotiplere ayırmada en fazla kabul gören ve en yaygın olarak kullanılan sistemdir. $\mathrm{Bu}$ sistemde, pvr2 lokusundaki $p v r 2^{1}$ ve $p v r 2^{2}$ dayanıklılık genlerine sahip biber (Capsicum annuum L.) genotiplerinin PVY biber izolatlarına verdikleri reaksiyonlara göre PVY-0, PVY-1 ve PVY-1,2 olmak üzere üç ayrı patotip altında sınıflandırılmaktadır (Gebre-Selassie ve ark. 1985). Resesif $p v r 2^{1}$ alleli PVY0 patotipine dayanıklılığ 1 , pvr2 ${ }^{2}$ alleli ise PVY-0 ve PVY-1'e karşı dayanıklılığı sağlamaktadır. PVY-1,2 patotipi ise her iki genin dayanıklılığını kırmaktadır (Palloix ve Kyle, 1995). Türkiye'de bugüne kadar yapılan çalışmalarda biber üretim alanlarında PVY-0 (Palloix ve ark. 1994; Çelik ve ark., 2012) ve PVY-1 (Palloix ve ark. 1994) patotipleri belirlenmiş̧tir.

Samsun ili 133563 tonluk üretimi ile (TUIK, 2018) Türkiye biber üretiminde önemli bir yere sahiptir. Bu çalışmada, Samsun ilinde biberde enfeksiyon oluşturan PVY'nin patotiplerinin belirlenmesi ve bu patotiplerin moleküler olarak karakterize edilmesi amaçlanmıştır.

\section{Materyal ve Yöntem}

\section{1 Örneklerin toplanmasl}

Örnekler, yapraklarda mozayik, mottle, damarlarda renk açılması, damar bantlaşması, bitki boyunun kısa 
olması gibi virüs ve virüs-benzeri belirti gösteren biber bitkilerinin genç yapraklarından alınmıştır. Samsun ili Çarşamba, Bafra, Terme ve Tekkeköy ilçelerine bağlı köylerdeki biber üretim alanlarından, her bir ilçenin ekiliş alanları oranında 2010 yılında 502, 2011 yılında ise 510 olmak üzere toplam 1012 örnek toplanmıştır. Örnekler, polietilen torbalara konularak etiketlenmiş ve serolojik olarak test edilinceye kadar $-20^{\circ} \mathrm{C}$ 'de derin dondurucuda saklanmıştır.

\subsection{PVY ile enfekteli örneklerin belirlenmesi ve izolatlarin elde edilmesi}

Biber örnekleri PVY'ye spesifik antiserumlar kullanılarak DAS-ELISA yöntemi ile test edilmiştir. ELISA sonucu PVY ile enfekteli çıkan örneklerde karışık enfeksiyonları belirlemek amacıyla pozitif örnekler Tobacco mosaic virus (TMV), Cucumber mosaic virus (CMV), Pepper mild mottle virus (PMMoV), Tomato mosaic virus (ToMV), Tomato spotted wilt virus (TSWV) ve Alfalfa mosaic virus (AMV)'ye spesifik antiserumlar kullanılarak DASELISA yöntemi ile tekrar test edilmiştir. Yöntem, Clark ve Adams (1977)'ın ve antiserumların temin edildiği firmaların (Bioreba, İsviçre) önerilerine göre uygulanmıştır. Testlemeler sonucunda negatif kontrolün iki katı ve üzerinde absorbans değerine sahip örnekler pozitif olarak kabul edilmiştir (Arlı Sökmen ve ark., 2005). Test sonucunda karışık enfeksiyon göstermeyen izolatlar belirlenmiş ve daha sonra her bir izolata numara verilerek izolatların çoğaltılmasına çalışılmıştır. Takiben, çoğaltılabilen Çarşamba ilçesine ait SÇ-9, SÇ77, SÇ-79, SÇ-81, SÇ-83, SÇ-84, SÇ-85, SÇ-86 ve SÇ87 izolatları ve Bafra ilçesine ait SB-12, SB-45, SB-62 ve SB-63 izolatları patotip belirleme çalışmalarına alınmıştır.

\subsection{Patotip ayrımında kullanılan biber çeşitleri}

PVY'nin patotiplerini belirlemek için GebreSelassie ve ark. (1985) tarafindan önerilen Yolo Wonder (Pvr0), Yolo Y ( $\left.p v r 2^{1}\right)$, Florida VR2 ( $\left.p v r 2^{2}\right)$ ve CM 334 (Pvr4) çeşitlerine ait tohumlar kullanılmıştır. Tohumlar North Central Regional Plant Introduction Station, Iowa State University, USDA-ARS, ABD'den temin edilmiştir.

\subsection{Patotip ayrim setindeki bitkilere virüs inokulasyonu ve patotiplerin belirlenmesi}

ELISA testleri sonucunda PVY ile enfekteli bulunan örnekler, çoğaltım konukçusu olan Yolo Wonder biber çeşidinde çoğaltılarak yeterli PVY inokulumunun elde edilmesine çalışılmıştır. Daha sonra her bir PVY izolatı, patotip ayrım setine ait 4 farklı biber çeşidine (Çizelge 1) 5 tekerrürlü olacak şekilde ayrı ayrı inokule edilmişlerdir. $\mathrm{Bu}$ amaçla Fosfat tampon çözeltisinde (0.02 M, pH: 7.0) 1:10 (gr/ml) oranında sulandırıldıktan sonra homojenize edilerek hazırlanan PVY izolatlarına ait inokulumlar, şaşırtma işleminden 1-2 gün sonra fidelere mekanik inokulasyon yöntemi ile bulaştırılmışlardır (Echer ve Costa, 2002; Çelik ve ark., 2012). İnokulasyon sonrası bitkiler, ortalama $25{ }^{\circ} \mathrm{C}$ sıcaklıktaki sera koşullarında 21 gün süreyle gözlenmiş ve simptomlar kaydedilmiştir. Ayrıca, bitkiler inokulasyondan 21 gün sonra DAS-ELISA yöntemi (Clark ve Adams, 1977) ile test edilmiştir. İnokulasyon sonrası sistemik belirti gösteren ve ELISA sonucu pozitif olan bitkiler hassas (S), sistemik belirti göstermeyen ve ELISA sonucu negatif olan bitkiler ise dayanıklı (R) olarak değerlendirilmiştir. Daha sonra ise patotip ayrım setindeki biber çeşitlerinin verdikleri reaksiyonlara göre (Çizelge 1) PVY patotipleri belirlenmiştir (Gebre-Selassie ve ark., 1985).

Çizelge 1. Patotip ayrım setindeki biber çeşitleri ve Potato virus $Y$ patotiplerine reaksiyonları

Table 1. Differential pepper cultivars used for detection of Potato virus $Y$ pathotypes and their reactions

\begin{tabular}{lccc}
\hline Çeşit/Genotip & PVY-0 & PVY-1 & PVY-1,2 \\
\hline Yolo Wonder (Pvr0) & $\mathrm{S}$ & $\mathrm{S}$ & $\mathrm{S}$ \\
Yolo Y (pvr2 $\left.{ }^{1}\right)$ & $\mathrm{R}$ & $\mathrm{S}$ & $\mathrm{S}$ \\
Florida VR2 $\left(p v r 2^{2}\right)$ & $\mathrm{R}$ & $\mathrm{R}$ & $\mathrm{S}$ \\
CM 334 (Pvr4) & $\mathrm{R}$ & $\mathrm{R}$ & $\mathrm{R}$ \\
\hline
\end{tabular}

R: Dayanıkli; S: Hassas

2.5 Reverse-Transkripsiyon-Polimeraz zincir reaksiyonu (RTPCR)

PVY patotipleri ile enfekteli biber bitkilerinden toplam RNA'lar Ambion PureLink RNA Mini Kit (Invitrogen) protokolüne göre izole edilmiştir. PVY patotiplerinin genomik RNA'sının bir bölümü (CP bölgesi) RT-PCR yöntemi ile çoğaltılmıştır. Primerler [CP1 (İleri yönlü primer): ATATCGGATCCGGAGAGACAC ve CP2 (Geri yönlü primer): CTAAGAAGCTTCACTGAAATG (Llave ve ark., 1999)] İontek (İstanbul) firması tarafindan sentezlenmiştir. PVY CP genini içeren 902 bp büyüklüğündeki bölgenin amplifikasyonu ve yeterli ürünün elde edilmesi amaciyla Qiagen OneStep RTPCR kiti kullanılarak tek aşamalı RT-PCR yöntemi uygulanmıştır. Reaksiyon bileşenleri, $5 \mu \mathrm{l}$ 5X Qiagen One step RT-PCR tampon çözeltisi, $1 \mu 110 \mathrm{mM}$ dNTPs, her bir primerden $0,15 \mu \mathrm{l}$, (son konsantrasyon: $0.6 \mu \mathrm{M}$ ), $1 \mu$ Qiagen RT-PCR enzim karışımı (Omniscript Reverse Transkriptaz, Sensiscript Reverse Transkriptaz ve HotStar Taq DNA Polimeraz) ve RNA (1 pg-2 $\mu \mathrm{g} /$ reaksiyon)'dan oluşmuştur. Toplam reaksiyon hacmi RNase ve DNase içermeyen su ile $25 \mu$ l'ye 
tamamlanmıştır. RT-PCR yöntemi, MJ Mini PCR termal döngü cihazında (Bio-Rad, ABD) gerçekleştirilmiş ve RT aşamas $150^{\circ} \mathrm{C}^{\prime} \mathrm{de} 30 \mathrm{dk}$, PCR aşaması ise $95{ }^{\circ} \mathrm{C}$ 'de $15 \mathrm{dk}, 35$ döngü olacak şekilde $94{ }^{\circ} \mathrm{C}$ 'de 30 sn, $58{ }^{\circ} \mathrm{C}$ 'de $1 \mathrm{dk}$ ve $72{ }^{\circ} \mathrm{C}$ 'de $1 \mathrm{dk}$ uygulanmış ve 1 döngü $72 \quad{ }^{\circ} \mathrm{C}$ 'de $5 \mathrm{dk}$ ile tamamlanmıştır. Reaksiyon sonucunda 902 bp büyüklüğünde bant oluşturması beklenmiştir. PCR sonrası oluşan DNA fragmentlerinin analizi için $8 \mu \mathrm{l}$ PCR ürününe $2 \mu$ y yükleme tamponu [\% 15 ficoll 400, $\%$ 0,03 bromophenol blue, \% 0,03 xylene cyanol FF, \% $0,4$ orange $\mathrm{G}, 10 \mathrm{mM}$ Tris- $\mathrm{HCl}$ (pH: 7,5$)$ ve $50 \mathrm{mM}$ EDTA] ilave edilmiştir. Daha sonra örnekler TBE tampon çözeltisinde ( $89 \mathrm{mM}$ Tris, $89 \mathrm{mM}$ borik asit ve 2 mM EDTA) hazırlanan \% 1'lik agaroz jelde $(0,5$ $\mu \mathrm{g} / \mathrm{ml}$ etidyum bromür içeren) $80 \mathrm{~mA}$ sürekli akımda 2 saat süre ile elektroforeze tabi tutulmuştur. Jeldeki PCR fragmentlerinin analizi GelDoc 2000 (Biorad, ABD) jel görüntüleme sistemi kullanılarak gerçekleştirilmiştir.

\subsection{Sekans analizi ve PVY biber izolatlarinin filogenetik ilişkilerinin araştırılması}

PVY'nin SÇ-9, SB-63, SÇ-84 ve SÇ-87 nolu izolatlarının kılıf protein gen bölgesi-nükleotid dizileri, Sanger Dizileme Yöntemi ile elde edilmiştir. Bu aşamada İontek (İstanbul) ve Genoks (Ankara) firmalarının sekans analizi hizmetinden yararlanılmıştır. CLC Main Workbench (Demo Version 7.03) programı kullanılarak PVY izolatlarına ait her iki yönde (ileri ve geri) elde edilen ham sekans verileri hizalanmış ve konsensus diziler elde edilmiştir. Daha sonra bu çalışmaya ait PVY izolatlarına ait konsensus diziler, diğer PVY izolatlarına ait diziler ile NCBI BLAST (https://blast.ncbi.nlm.nih.gov/Blast.cgi) kullanılarak moleküler düzeyde karşılaş̧ırılmıştır. Ayrıca, Mega 7 programında bulunan ClustalW (Thompson ve ark., 1994) analiz yöntemi kullanılarak bu çalışmaya ait dört PVY izolatının, NCBI'dan indirilen 41 referans PVY izolatının ve dış grup olarak kullanılan Bean common mosaic virus (Çizelge 2) NL-1 ırkının (KM023744) nükleotit dizileri hizalanmıştır. Daha sonra Kimura-2 parametre yöntemi (transisyon/transversiyon oranı: 2.0) (Kimura, 1980) ile genetik uzaklıklar belirlenmiş ve Neighbor-Joining (NJ) algoritmasına göre (Saitou ve Nei, 1987) filogenetik ağaç oluşturulmuştur. Filogenetik analizde Bootstrap değeri olarak 1000 alınmıştır. Sonuçların tutarlılığını kontrol etmek amacıyla aynı nükleotid dizileri MEGA 7 yazılımında yer alan Maximum likelihood (ML) yöntemi (Felsenstein, 1981) kullanılarak da analiz edilmiş ve bu yönteme göre elde edilen dendrogram, $\mathrm{NJ}$ yöntemi ile elde edilen dendrogram ile kıyaslanmış ve sonuçlar tek bir filogenetik ağaç olarak verilmiştir.

\section{Bulgular ve Tartışma}

\subsection{Samsun ilinde biber üretim alanlarında PVY'nin bulunma durumu}

Samsun ilinde biber üretim alanlarından alınan örneklerin DAS-ELISA yöntemi ile test edilmeleri sonucunda 2010 yılında toplanan 502 örneğin \%11.9'unun PVY ile enfekteli olduğu belirlenmiştir. Bafra ilçesine ait 202 örneğin \% 19.3'ü, Çarşamba ilçesine ait 245 örneğin \% 7.3'ü, Terme ilçesine ait 36 örneğin \% 8.3'ü PVY ile enfekteli olarak bulunmuştur. Tekkeköy ilçesinde ise test edilen 19 örneğin tamamında PVY' ye rastlanılmamıştır (Çizelge 3). 2011 yılında ise incelenen 510 örneğin \% 5.8'inin PVY ile enfekteli olduğu belirlenmiştir. Bu yıla ait Çarşamba ilçesinde toplanan 227 örneğin \% 7.9'u, Bafra ilçesinde 227 örneğin \% 2.6'sı, Terme ilçesinde ise 46 örneğin \% 2.1 ' $\mathrm{i}$, Tekkeköy ilçesinde ise test edilen 10 örneğin \% 50'si PVY ile enfekteli bulunmuştur (Çizelge 3). Her iki y1l birlikte değerlendirildiğinde toplam 1012 biber örneğinin \% 8.9'u PVY ile enfekteli olarak belirlenmiștir. Arlı Sökmen ve ark. (2005), 1998 ve 1999 yıllarında Samsun ilinde biber üretim alanlarında en yaygın virüs türü olarak PVY ( $\%$ 24.6)'yi belirlemişlerdir. Geçmiş yıllara oranla, PVY'nin Samsun ilindeki biber üretim alanlarında daha düşük oranda belirlenmesinin nedeninin, üreticiler tarafından son yıllarda vektör yaprak bitlerine karşı daha etkili mücadele edilmesi ve vektörün popülasyonunun azalması ile ilgili olabileceği düşünülmüştür. Daha sonraki bir başka çalışmada, Hatay, Kahramanmaraş, Şanlıurfa ve Gaziantep illerindeki biber üretim alanlarından alınan örneklerde PVY'nin \% 26.4 ile en sık rastlanan virüs olduğu belirlenmiştir (Buzkan ve ark., 2006). Antalya ilinde ise 2007 ve 2008 yıllarında biber üretim alanlarından toplanan 274 örnekte PVY'nin bulunma oranı ise \% 7.6 olarak belirlenmiştir (Çelik ve ark., 2012).

Bu çalışmada daha sonra, PVY ile enfekteli olarak belirlenen 90 örneğin biberde enfeksiyon oluşturabilen ve sıklıkla rastlanan diğer virüslerle karışık enfekteli olup olmadığı, ELISA yöntemi ile araştırılmıştır. PVY ile enfekteli örneklerin 24 (\%26.6)'ünün diğer virüslerle karışık-enfekteli olduğu belirlenmiştir. PVY ile karışık enfeksiyonu belirlenen virüsler ve sayıları şu şekildedir: CMV (13), TSWV (9), PMMoV (1) ve CMV+TSWV (1). Test edilen örneklerde AMV, TMV ve ToMV enfeksiyonuna ise rastlanmamıştır. PVY ile karışık enfeksiyon oluşturduğu belirlenen PMMoV, Samsun ilinde ilk defa tespit edilmiştir. Arlı Sökmen ve ark. (2005), 1998 ve 1999 yıllarında yaptıkları çalışmada, Samsun ilinde biber üretim alanlarında AMV, CMV, PVY, ToMV, TMV ve TSWV'nin bulunduğunu belirlemişlerdir. Ayrıca, en yaygın karışık enfeksiyonun, TMV+PVY (\% 15.4) ikili enfeksiyonu olduğunu bildirmişlerdir. 
Çizelge 2. Filogenetik analizde kullanılan Potato virus $Y$ izolatları

Table 2. Potato virus $Y$ isolates used in phylogenetic analysis

\begin{tabular}{|c|c|c|c|c|c|}
\hline Grup & $\begin{array}{c}\text { İzolat } \\
\text { Adı }\end{array}$ & $\begin{array}{l}\text { GenBank } \\
\text { Kayit No }\end{array}$ & Ülke & Bitki & Patotip/Irk \\
\hline ?* & SÇ-9 & KJ847048 & Türkiye & Biber & PVY-0 \\
\hline ? & SB-63 & KJ847047 & Türkiye & Biber & PVY-0 \\
\hline ? & SÇ-84 & KJ847045 & Türkiye & Biber & PVY-1 \\
\hline$?$ & SÇ-87 & KJ847046 & Türkiye & Biber & PVY-1 \\
\hline $\mathrm{C} 1$ & Tu12.3 & AJ303095 & Türkiye & Biber & PVY-1 \\
\hline $\mathrm{C}$ & LYE 84.2 & AJ439545 & İspanya & Domates & PVY-0 \\
\hline ? & $\mathrm{Si}-15$ & AJ303093 & İtalya & Biber & PVY-1 \\
\hline $\mathrm{C}$ & SON-41 & AJ439544 & Fransa & Solanum nigrum & PVY-1,2 \\
\hline $\mathrm{C}$ & PRI-509 & EU563512 & Hollanda & Patates & $\mathrm{PVY}^{\mathrm{C}}$ \\
\hline $\mathrm{C}$ & YC Zb & JF804785 & Polonya & Patates & $\mathrm{PVY}^{\mathrm{C}}$ \\
\hline $\mathrm{O}$ & PVY-Kh81 & EF192311 & İran & Patates & $\mathrm{PVY}^{\mathrm{O}}$ \\
\hline $\mathrm{N}$ & SASA 207 & AJ584851 & Birleşik Krallık & Patates & $\mathrm{PVY}^{\mathrm{N}}$ \\
\hline $\mathrm{N}$ & Cou8/03 & JF804780 & Polonya & Patates & $\mathrm{PVY}^{\mathrm{NTN}}$ \\
\hline $\mathrm{N}$ & РB312 & EF026075 & $\mathrm{ABD}$ & Patates & $\mathrm{PVY}^{\mathrm{NTN}}$ \\
\hline $\mathrm{C}$ & nnp & AF237963 & İtalya & Biber & Biber damar nekroz 1rk1 \\
\hline$?$ & HNJJ & MK190679 & Çin & Tütün & ? \\
\hline ? & PVYO:N-Iraq2 & JQ026009 & Irak & Patates & ? \\
\hline $\mathrm{N}$ & Tu 660 & AY166866 & $\mathrm{ABD}$ & Patates & $\mathrm{PVY}^{\mathrm{NTN}}$ \\
\hline $\mathrm{O}$ & SASA-110 & AJ585195 & Birleşik Krallık & Patates & $\mathrm{O}$ \\
\hline $\mathrm{C}$ & PVY-MN & AF463399 & $\mathrm{ABD}$ & $?$ & MN \\
\hline $\mathrm{C}$ & NC57 & DQ309028 & ABD & Tütün & $?$ \\
\hline $\mathrm{C}$ & Foggia & EU482153 & İtalya & Domates & ? \\
\hline $\mathrm{C}$ & Adgen & AJ890348 & Fransa & Patates & ? \\
\hline $\mathrm{C} 1$ & PVY-1055 & КР063211 & İran & Tütün & ? \\
\hline $\mathrm{O}$ & SCRI-O & AJ585196 & Birleşik Krallık & Patates & $?$ \\
\hline $\mathrm{O}$ & PVY-Oz & EF026074 & $\mathrm{ABD}$ & Patates & ? \\
\hline $\mathrm{O}$ & Co1898 & HQ912906 & $\mathrm{ABD}$ & Patates & ? \\
\hline $\mathrm{C} 2$ & $\mathrm{C} 27$ & AF012026 & $?$ & $?$ & ? \\
\hline $\mathrm{C} 1$ & P21-82 & AJ005639 & $?$ & Biber & $?$ \\
\hline $\mathrm{N}$ & Mont & AY884983 & $\mathrm{ABD}$ & $?$ & $?$ \\
\hline $\mathrm{N}$ & N605 & X97895 & İsviçre & $?$ & ? \\
\hline$?$ & Si-15-Turk & AJ303094 & Türkiye & Biber & ? \\
\hline$?$ & P21-82 & AJ303097 & İspanya & Biber & $?$ \\
\hline $\mathrm{N}$ & Satina & AJ890347 & Almanya & Patates & $\mathrm{PVY}^{\mathrm{NTN}}$ \\
\hline $\mathrm{O}$ & NT-25 & JQ924285 & Brezilya & Patates & $\mathrm{O}$ \\
\hline $\mathrm{C} 1$ & PV-0890 & КР063208 & İran & Biber & $?$ \\
\hline $\mathrm{O}$ & NE-38 & KY848004 & $\mathrm{ABD}$ & Patates & ? \\
\hline Wilga & 156var & AJ889868 & Almanya & Patates & ? \\
\hline $\mathrm{O}$ & v951204 & AJ390292 & Birleşik Krallık & Patates & ? \\
\hline $\mathrm{N}$ & WA316 & KY848025 & $\mathrm{ABD}$ & Patates & ? \\
\hline ? & SC-1-1-2 & KX688602 & Çin & Patates & ? \\
\hline $\mathrm{O}$ & LW & AJ890349 & Polonya & Patates & ? \\
\hline $\mathrm{O}$ & PVY-KZNU & KU695256 & Güney Afrika & Physalis peruviana & ? \\
\hline $\mathrm{O}$ & O803 & AJ223594 & İsviçre & ? & ? \\
\hline $\mathrm{O}$ & AL100001 & KY847935 & $\mathrm{ABD}$ & Tütün & ? \\
\hline
\end{tabular}




\subsection{Samsun ilinde belirlenen PVY patotipleri}

Test edilen diğer virüs türleri ile karışık-enfekteli olmadığı belirlenen ve hassas biber çeşidi Yolo Wonder'a inokule edilerek çoğaltımı sağlanabilen 13 PVY izolatı, patotiplerinin araştırılması için seçilmiştir. Çoğaltımı sağlanan PVY izolatları patotip ayrım setindeki 4 farklı biber çeşidine ayrı ayrı inokule edilmiştir. Patotip ayrım setindeki bitkilerin PVY izolatlarına verdikleri reaksiyonlara ve ELISA sonuçlarına göre, PVY izolatlarından 9 tanesi (SÇ-9, SB-12, SB-45, SB-63, SÇ-77, SÇ-79, SÇ-81, SÇ-83 ve SÇ-85 nolu izolatlar) sadece Yolo Wonder çeşidinde sistemik mozayik oluşturarak hassas reaksiyona neden olmuştur (Şekil 1). Ayrıca, incelenen tüm çeşitler, inokulasyondan 21 gün sonra PVY'ye spesifik antiserum kullanılarak ELISA ile test edilmiş ve sadece Yolo Wonder çeşidine ait bitkiler PVY antiserumu ile pozitif reaksiyon oluşturmuştur. Virüs inokulasyon ve ELISA sonuçları, incelenen 9 PVY izolatının PVY-0 patotipine ait olduğunu ortaya koymuştur (Çizelge 4). Diğer taraftan, 4 PVY izolatı (SB-62, SÇ-84, SÇ-86 ve SÇ-87 nolu izolatlar) hem Yolo Wonder hem de Yolo Y çeşitlerinde sistemik enfeksiyona sebep olmuş (Şekil 2) ve bu çeşitlere ait bitkiler ELISA ile de enfekteli bulunmuştur. Söz konusu izolatlara karşı Florida VR-2 ve CM-334 çeşitlerinin dayanıklı olduğu belirlenmiştir. $\mathrm{Bu}$ sonuçlara göre, SB-62, SÇ-84, SÇ-86 ve SÇ-87 izolatlarının PVY-1 patotipine ait olduğu belirlenmiştir (Çizelge 4).

Çalışma sonucunda, Samsun ilinde biber üretim alanlarında PVY-0 ve PVY-1 patotipleri belirlenmiştir. PVY-1,2 patotipi ise tespit edilmemiștir. Benzer bir şekilde Palloix ve ark. (1994), Akdeniz Bölgesi’ndeki biber üretim alanlarında patotip ayrım setini kullanarak PVY'nin patotiplerini araştırmışlar ve çalışma sonucunda PVY-0 ve PVY-1 patotiplerini belirlemişlerdir. Buzkan ve ark. (2012), 2010 ve 2011 yıllarında Gaziantep, Kahramanmaraș ve Hatay illerinde biber üretim alanlarından topladıkları örneklerden PVY ile enfekteli bir izolatın patotip ayrım seti kullanarak PVY-1 patotipi olduğunu belirlemişlerdir. Çelik ve ark. (2012), Antalya'da 2007 ve 2008 y1llarında biber üretim alanlarından topladıkları toplam 21 PVY izolatının patotiplerini, patotip ayrım setini kullanarak belirlemişler ve izolatların tamamının PVY'nin 0 patotipi olduğunu ortaya koymuşlardır. PVY-0 patotipi Fransa, İtalya ve İspanya gibi Akdeniz ülkelerinde de en yaygın patotip olarak bilinmektedir (Caranta ve ark., 1999). Bu çalışmada da benzer bir șekilde Samsun ilinde PVY-0'ın en yaygın (\% 69.2) patotip olduğu ortaya konulmuştur.

\subsection{PVY patotiplerinin moleküler karakterizasyonu}

$\mathrm{Bu}$ çalışmada, PVY-0 patotipine ait SÇ-9 (KJ847048) ve SB-63 (KJ847047) izolatlarının ve PVY-1 patotipine ait SÇ-84 (KJ847045) izolatının CP bölgesinin tamamının, PVY-1 patotipi olarak belirlenen SÇ-87 (KJ847046) izolatının ise kısmi sekans verileri elde edilmiş ve GenBank'a yukarıda belirtilen numaralar ile kayıt edilmiştir. Bu çalışmadaki biber izolatlarının, PVY genomundaki pozisyonlarının belirlenmesinde GenBank Kayıt Numarası NC_001616 olan PVY izolatının genomu esas alınmıştır. (NC_001616 kayıt numaralı izolatın kılıf protein bölgesi, 8573-9373 nükleotidleri arasında yer almaktadır). Daha sonra GenBank'da kayıtlı diğer PVY izolatları ile nükleotid BLAST (BLASTn) yöntemi ile karşılaşıtırılmıştır. İzolatlara ait elde edilen nükleotid dizilerinin büyüklükleri, PVY genomundaki pozisyonları ve benzerlik oranları Çizelge 5'de verilmiştir.

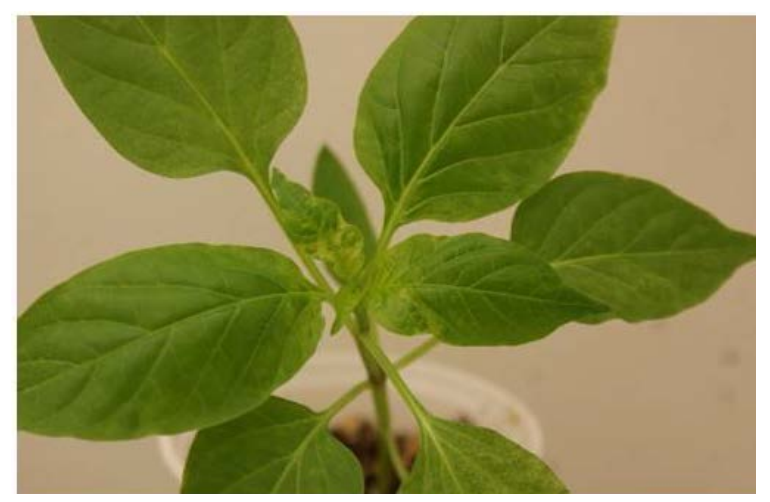

Şekil 1. SB-12 nolu izolat (PVY-0) ile inokule edilen Yolo Wonder biber çeşidinin yapraklarında oluşan mozayik simptomu

Figure 1. Mosaic symptom on leaves of pepper cultivar "Yolo Wonder" after inoculation with the SB-12 (PVY-0)

SÇ-9 (PVY-0), SÇ-84 (PVY-1) ve SÇ-87 (PVY-1) nolu izolatların, daha önceki bir çalışmada Türkiye'den elde edilmiş olan ve PVY-1 patotipine ait biber izolatı Tu12.3 (AJ303095) ve İspanya'daki bir çalışmada elde edilmiş olan ve PVY-0 patotipine ait olan domates izolatı LYE 84.2 (AJ439545) ile en yüksek nükleotid benzerlik oranına (\% 97-98) sahip olduğu belirlenmiştir. Her üç izolat da PVY-1,2 patotipine ait Fransa orjinli SON-41 izolatı ile daha düşük oranda (\% 94-96) benzerlik göstermiştir (Çizelge 5). Bu durum, biberi enfekte eden PVY-0 ve PVY-1 patotiplerinin CP bölgesi bakımından birbirine çok benzer, PVY-1,2 patotipine ise daha düşük oranda benzer olduğunu göstermiştir. Llave ve ark. (1999), İspanya'da biber yetiştirilen alanlardan elde edilen PVY patotipleri PVY-0, PVY-1 ve PVY-1,2'nin CP nükleotid ve aminoasit dizilerini karşılaştırmışlar ve en yüksek (\% 99.2) dizi benzerliğinin 0 ve 1 patotipi arasında olduğunu, 0 ve 1 patotipleri ile patotip 1,2 arasında ise daha düşük (\% 98.1) benzerliğin bulunduğunu belirlemişlerdir. 
Çizelge 3. Samsun ilinden alınan biber örneklerinin Potato virus $Y$ ile bulaşıklık oranları

Table 3. Incidence of Potato virus $Y$ in pepper samples collected in Samsun province

\begin{tabular}{cccc}
\hline Yıl & İlçe & Enfekteli Örnek/Toplam Örnek & Enfeksiyon Oranı (\%) \\
\hline \multirow{3}{*}{2010} & Çarşamba & $18 / 245$ & 7.3 \\
& Bafra & $39 / 202$ & 19.3 \\
& Terme & $3 / 36$ & 8.3 \\
& Tekkeköy & $0 / 19$ & 0.0 \\
& Toplam & $60 / 502$ & 11.9 \\
\cline { 2 - 4 } 2011 & Çarşamba & $18 / 227$ & 7.9 \\
& Bafra & $6 / 227$ & 2.6 \\
& Terme & $1 / 46$ & 2.1 \\
& Tekkeköy & $5 / 10$ & 50.0 \\
& Toplam & $30 / 510$ & 5.8 \\
\hline
\end{tabular}

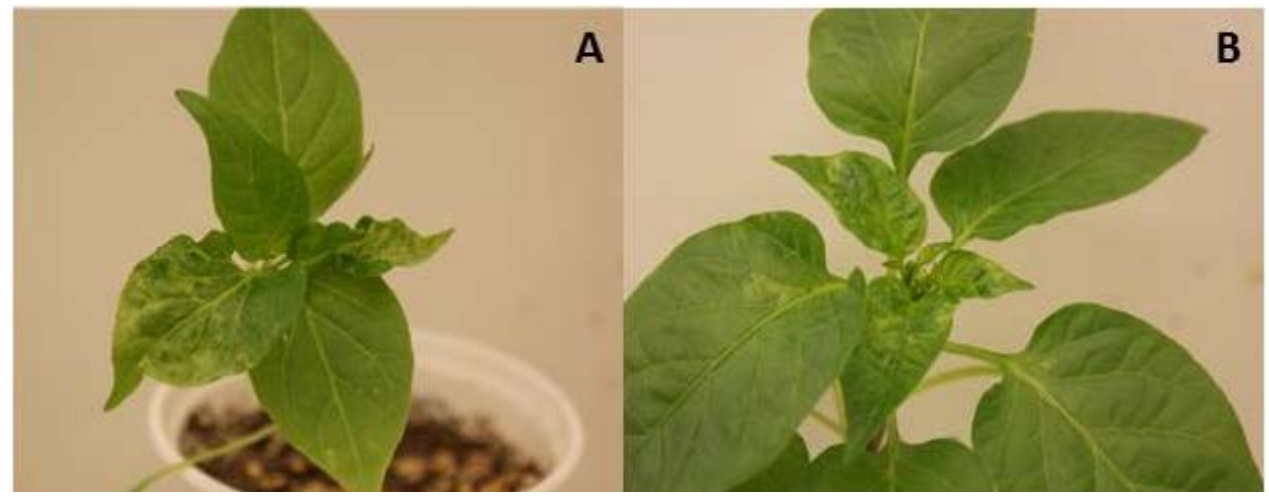

Şekil 2. SÇ-87 nolu izolatın (PVY-1), Yolo Wonder (A) ve YoloY (B) biber çeşidinin üst yapraklarında oluşturduğu mozayik simptomu

Figure 2. Mosaic symptom on upper leaves of pepper cultivars "Yolo Wonder" (A) and "Yolo Y" (B) inoculated with the isolate SÇ-87 (PVY-1),

Bu çalışmada, PVY'nin SÇ-9, SÇ-84 ve SÇ-87 izolatlarının, patateste enfeksiyon oluşturan izolatlarla genetik olarak daha uzak (\%88-96) ilişkiye sahip olduğu gözlenmiştir. Çalışmada ele alınan bu üç izolatın, $\mathrm{PVY}{ }^{\mathrm{C}}$ 1rkı ile ilişkili patates izolatlarına daha yüksek oranda (\%95-96) benzer bulunması (Çizelge 5), izolatların $\mathrm{PVY}^{\mathrm{C}}$ 1rkı ile yakın ilişkili olduğuna işaret etmiştir. Benzer şekilde, Buzkan ve ark. (2015), Hatay ilinde biber üretim alanlarından elde ettikleri PVY izolatlarının VPg ve CP geni dizi analizlerine göre tamamının $\mathrm{C}$ ırk grubunda yer aldığını ortaya koymuşlardır. Blanco-Urgoiti ve ark. (1998), pek çok biber izolatının patatesteki $\mathrm{PVY}{ }^{\mathrm{C}}$ izolatları ile yakından ilişkili olduğunu ve serolojik, biyolojik ve moleküler analizler (CP geni dizisi ve RFLP analizleri) sonucuna göre hemen hemen tüm biber izolatlarının C 1 rk grubunda yer aldığını belirlemişlerdir.

Kılıf protein bölgesi nükleotid dizi analizi sonucuna göre, PVY biber izolatlarının diğer PVY izolatları ile genetik ilişkilerini belirlemek amacıyla, farklı bitki türlerine ve lokasyonlara ait PVY izolatlarının (Çizelge 2) ve bir adet dış izolatın (Bean common mosaic virusBCMV) nükleotid dizileri kullanılarak filogenetik ağaç oluşturulmuştur. Neighbor-Joining (NJ) algoritmasına göre ve 1000 Bootstrap değeri seçilerek oluşturulan dendrogramın istatistiksel açıdan güvenilir olduğu gözlenmiştir (Şekil 3). Kılıf protein bölgesi için oluşturulan filogenetik ağaç incelendiğinde, Samsun'da biber alanlarından elde edilen SB-63 izolatının PVY-0 patotipine ait olmasına rağmen, patates bitkisinde saptanmış olan $\mathrm{N}$ grubu izolatlar ile aynı grupta yer 
Çizelge 4. Patotip ayrım setine ait biber çeşitlerinin Potato virus Y (PVY) izolatlarına verdikleri reaksiyonlar ve Samsun'da belirlenen PVY patotipleri

Table 4. Reactions of differential pepper cultivars against to Potato virus $Y$ (PVY) isolates and PVY pathotypes determined in Samsun province

\begin{tabular}{|c|c|c|c|c|c|c|c|c|c|c|c|}
\hline \multirow{3}{*}{ İzolat } & \multirow{3}{*}{ İlçe } & \multirow{3}{*}{ Köy } & \multicolumn{8}{|c|}{ Patotip Ayrım Reaksiyonları } & \multirow{3}{*}{ Patotip } \\
\hline & & & \multicolumn{2}{|c|}{ Yolo Wonder } & \multicolumn{2}{|c|}{ Yolo Y } & \multicolumn{2}{|c|}{ Florida VR-2 } & \multicolumn{2}{|c|}{ CM-334 } & \\
\hline & & & Reaksiyon & ELISA & Reaksiyon & ELISA & Reaksiyon & ELISA & Reaksiyon & ELISA & \\
\hline SÇ-9 & Çarşamba & Vakıfköprü & S & + & $\mathrm{R}$ & - & $\mathrm{R}$ & - & $\mathrm{R}$ & - & PVY-0 \\
\hline SB-12 & Bafra & Ağıllar & S & + & $\mathrm{R}$ & - & $\mathrm{R}$ & - & $\mathrm{R}$ & - & PVY-0 \\
\hline SB-45 & Bafra & Adaköy & S & + & $\mathrm{R}$ & - & $\mathrm{R}$ & - & $\mathrm{R}$ & - & PVY-0 \\
\hline SB-62 & Bafra & Yağmurca & S & + & S & + & $\mathrm{R}$ & - & $\mathrm{R}$ & - & PVY-1 \\
\hline SB-63 & Bafra & Yağmurca & S & + & $\mathrm{R}$ & - & $\mathrm{R}$ & - & $\mathrm{R}$ & - & PVY-0 \\
\hline SÇ-77 & Çarşamba & Bafracalı & S & + & $\mathrm{R}$ & - & $\mathrm{R}$ & - & $\mathrm{R}$ & - & PVY-0 \\
\hline SÇ-79 & Çarşamba & Kumarlı & S & + & $\mathrm{R}$ & - & $\mathrm{R}$ & - & $\mathrm{R}$ & - & PVY-0 \\
\hline SÇ-81 & Çarşamba & Kumarlı & S & + & $\mathrm{R}$ & - & $\mathrm{R}$ & - & $\mathrm{R}$ & - & PVY-0 \\
\hline SÇ-83 & Çarşamba & Kirazbucağ 1 & S & + & $\mathrm{R}$ & - & $\mathrm{R}$ & - & $\mathrm{R}$ & - & PVY-0 \\
\hline SÇ-84 & Çarşamba & Y.Karacalı & S & + & S & + & $\mathrm{R}$ & - & $\mathrm{R}$ & - & PVY-1 \\
\hline SÇ-85 & Çarşamba & Y.Karacalı & S & + & $\mathrm{R}$ & - & $\mathrm{R}$ & - & $\mathrm{R}$ & - & PVY-0 \\
\hline SÇ-86 & Çarşamba & Y.Karacalı & S & + & S & + & $\mathrm{R}$ & - & $\mathrm{R}$ & - & PVY-1 \\
\hline SÇ-87 & Çarşamba & Y.Karacalı & S & + & S & + & $\mathrm{R}$ & - & $\mathrm{R}$ & - & PVY-1 \\
\hline
\end{tabular}

S: Hassas, R: Dayanıklı, -:Negatif, +: Pozitif

aldığ gözlenmiştir. SÇ-9, SÇ-84 ve SÇ-87 izolatları ise C grubu izolatlar ile ayrı bir dalda kümelenmiştir. Şekil 3 ve Çizelge 2 birlikte değerlendirildiğinde $\mathrm{N}$ grubu izolatların $\% 82$ bootstrap değeriyle desteklenen ayrı bir ana dalda, $\mathrm{O}$ ve $\mathrm{C}$ grubu izolatların ise $\% 81$ bootstrap değeriyle diğer bir ana dalda yer aldığ 1 görülmektedir. Sadece N grubundaki tek bir PVY izolatı (AJ584851) O ve $\mathrm{C}$ grubu izolatlar ile dendrogramda aynı kolda yer almışıır. PVY izolatlarının aralarındaki genetik ilişkilerin incelendiği önceki bazı çalışmalarda da dünya PVY izolatlarının 2 ana kola ayrıldığı rapor edilmiştir. CP bölgesine göre yapılan filogenetik analizlerde birinci grubun nekrotik ve rekombinant irklardan (PVY-NTN, PVY- ${ }^{\mathrm{N}}$, PVY- ${ }^{\mathrm{NWi}}$ ve $\mathrm{PVY}-\mathrm{N} / \mathrm{P}$ ), diğer grubun ise $\mathrm{PVY}{ }^{\mathrm{C}}$ ve $P V Y^{O}$ irklarından oluștuğu rapor edilmiștir (Van der Vlugt ve ark., 1993; Abdalla ve ark., 2016).

$\mathrm{Bu}$ çalışmada, $\mathrm{CP}$ nükleotid dizi analizleri sonucunda dört izolat içerisinde en farklı izolatın, Bafra ilçesinden elde edilen PVY-0 patotipine ait SB-63 nolu izolat olduğu ortaya konulmuştur. SB-63 izolatının CP bölgesinin, patateste enfeksiyon oluşturan ve PVY ${ }^{\text {NTN }}$ ırkına dahil olan ABD orjinli PB312 (EF026075) ve Polonya orjinli Cou8/03 (JF804780) izolatlarına nükleotid düzeyinde $\% 99$ benzer olduğu belirlenmiştir (Çizelge 5). Bu izolatın Türkiye biber izolatları ile genetik benzerliği ise düşük (\% 90) bulunmuştur. $\mathrm{Bu}$ sonuçlar SB-63 nolu izolatın patates orijinli olabileceğini ya da rekombinat bir trk olabileceğine işaret etmiştir. Soto ve ark. (1994), PVY'nin biber ve patates izolatlarının daha çok biber ve patatese özgü olduklarını ve aralarındaki geçişlerin sınırlı olduğunu bildirmişlerdir. Bununla birlikte, diğer taraftan PVY'nin patates izolatlarının laboratuvar şartlarında biberi enfekte edebildiği ile ilgili çalışmalar bulunmaktadır (Heldak, 1997; Kazinczi ve ark., 2003). Ayrıca, SB-63 izolatının CP bölgesine ait ileri ve geri yönlü primerler kullanılarak elde edilen sekans dizisi sonucu incelendiğinde, tek noktada (Şekil 4'de 117. nükleotid) değişimin olduğu, her iki sekans dizisinde de tek noktada Timin veya Guanin içeren piklerin bulunduğu gözlenmiştir. $\mathrm{Bu}$ durum, SB-63nolu izolatın bu pozisyonda Urasil (U) veya Guanin $(\mathrm{G})$ içeren iki farklı PVY popülasyonu içerdiğine işaret etmiştir. Karışık virüs popülasyonlarının olması rekombinasyon ihtimalini de artırmaktadır. Potyvirus cinsinde yer alan virüs türlerinin doğada rekombinasyon yoluyla yeni ırklar oluşturabildiği bilinmektedir. PVY ${ }^{\mathrm{NTN}}$ ırkının, $\mathrm{PVY}^{\mathrm{N}}$ ve $\mathrm{PVY}^{\mathrm{O}}$ irklarına ait izolatların rekombinasyonları sonucunda oluşan patatese özgü bir ırk olduğu bildirilmiştir (Ogawa ve ark., 2008). 
Çizelge 5. Potato virus $Y$-biber izolatlarının kılıf protein (CP)bölgesi GenBank BLASTn analiz sonuçları Table 5. Results of GenBank BLASTn analysis for the coat protein $(C P)$ region of Potato virus $Y$-pepper isolates

\begin{tabular}{|c|c|c|c|c|c|c|c|c|c|}
\hline $\begin{array}{c}\text { İzolat } \\
\text { No }\end{array}$ & Patotip & $\begin{array}{l}\text { Sekans } \\
\text { Uzunluğu } \\
\text { (bp) }\end{array}$ & $\begin{array}{c}\text { Genom } \\
\text { Pozisyonu* }\end{array}$ & $\begin{array}{l}\text { Benzeşen } \\
\text { İzolat adı }\end{array}$ & $\begin{array}{c}\text { Erişim } \\
\text { Numarası }\end{array}$ & $\begin{array}{c}\text { Orijin } \\
\text { Ülke }\end{array}$ & $\begin{array}{l}\text { Orijin } \\
\text { Bitki }\end{array}$ & Patotip/Irk & $\begin{array}{c}\text { Benzerlik } \\
(\%)\end{array}$ \\
\hline \multirow{11}{*}{ SÇ-9 } & \multirow{11}{*}{ PVY-0 } & \multirow{11}{*}{879} & \multirow{11}{*}{ 8498-9376 } & Tu12.3 & AJ303095 & Türkiye & Biber & PVY-1 & 97 \\
\hline & & & & LYE 84.2 & AJ439545 & İspanya & Domates & PVY-0 & 97 \\
\hline & & & & K16.94 & AJ303094 & Tunus & Biber & PVY-1 & 95 \\
\hline & & & & Si-15 & AJ303093 & İtalya & Biber & PVY-1 & 95 \\
\hline & & & & SON-41 & AJ439544 & Fransa & S. nigrum & PVY-1,2 & 94 \\
\hline & & & & PRI-509 & EU563512 & Hollanda & Patates & $\mathrm{PVY}^{\mathrm{C}}$ & 95 \\
\hline & & & & YC Zb & JF804785 & Polonya & Patates & $\mathrm{PVY}^{\mathrm{C}}$ & 95 \\
\hline & & & & PVY-Kh81 & EF192311 & İran & Patates & $\mathrm{PVY}^{\mathrm{O}}$ & 93 \\
\hline & & & & SASA 207 & AJ584851 & UK & Patates & $\mathrm{PVY}^{\mathrm{N}}$ & 91 \\
\hline & & & & Cou8/03 & JF804780 & Polonya & Patates & $\mathrm{PVY}^{\mathrm{NTN}}$ & 88 \\
\hline & & & & PB312 & EF026075 & $\mathrm{ABD}$ & Patates & $\mathrm{PVY}^{\mathrm{NTN}}$ & 88 \\
\hline \multirow{11}{*}{ SB-63 } & \multirow{11}{*}{ PVY-0 } & \multirow{11}{*}{881} & \multirow{11}{*}{$8510-9390$} & PB312 & EF026075 & $\mathrm{ABD}$ & Patates & $\mathrm{PVY}^{\mathrm{NTN}}$ & 99 \\
\hline & & & & Cou8/03 & JF804780 & Polonya & Patates & $\mathrm{PVY}^{\mathrm{NTN}}$ & 99 \\
\hline & & & & PVY-Kh81 & EF192311 & İran & Patates & $\mathrm{PVY}^{\mathrm{O}}$ & 92 \\
\hline & & & & Tu12.3 & AJ303095 & Türkiye & Biber & PVY-1 & 90 \\
\hline & & & & K16.94 & AJ303094 & Tunus & Biber & PVY-1 & 90 \\
\hline & & & & Si-15 & AJ303093 & İtalya & Biber & PVY-1 & 90 \\
\hline & & & & SON-41 & AJ439544 & Fransa & S. nigrum & PVY-1,2 & 90 \\
\hline & & & & SASA 207 & AJ584851 & UK & Patates & $\mathrm{PVY}^{\mathrm{N}}$ & 91 \\
\hline & & & & LYE 84.2 & AJ439545 & İspanya & Domates & $\mathrm{PVY}^{\mathrm{O}}$ & 89 \\
\hline & & & & PRI-509 & EU563512 & Hollanda & Patates & $\mathrm{PVY}^{\mathrm{C}}$ & 89 \\
\hline & & & & YC Zb & JF804785 & Polonya & Patates & $\mathrm{PVY}^{\mathrm{C}}$ & 89 \\
\hline \multirow{11}{*}{ SÇ-84 } & \multirow{11}{*}{ PVY-1 } & \multirow{11}{*}{885} & \multirow{11}{*}{ 8508-9391 } & Tu12.3 & AJ303095 & Türkiye & Biber & PVY-1 & 98 \\
\hline & & & & LYE 84.2 & AJ439545 & İspanya & Domates & PVY-0 & 97 \\
\hline & & & & $\mathrm{Si}-15$ & AJ303093 & İtalya & Biber & PVY-1 & 96 \\
\hline & & & & K16.94 & AJ303094 & Tunus & Biber & PVY-1 & 95 \\
\hline & & & & SON-41 & AJ439544 & Fransa & S. nigrum & PVY-1,2 & 95 \\
\hline & & & & PRI-509 & EU563512 & Hollanda & Patates & $\mathrm{PVY}^{\mathrm{C}}$ & 95 \\
\hline & & & & YC Zb & JF804785 & Polonya & Patates & $\mathrm{PVY}^{\mathrm{C}}$ & 95 \\
\hline & & & & PVY-Kh81 & EF192311 & İran & Patates & $\mathrm{PVY}^{\mathrm{O}}$ & 93 \\
\hline & & & & SASA 207 & AJ584851 & UK & Patates & $\mathrm{PVY}^{\mathrm{N}}$ & 91 \\
\hline & & & & Cou8/03 & JF804780 & Polonya & Patates & $\mathrm{PVY}^{\mathrm{NTN}}$ & 89 \\
\hline & & & & PB312 & EF026075 & $\mathrm{ABD}$ & Patates & $\mathrm{PVY}^{\mathrm{NTN}}$ & 89 \\
\hline \multirow{11}{*}{ SÇ-87 } & \multirow{11}{*}{ PVY-1 } & \multirow{11}{*}{806} & \multirow{11}{*}{ 8586-9390 } & Tu12.3 & AJ303095 & Türkiye & Biber & PVY-1 & 98 \\
\hline & & & & LYE 84.2 & AJ439545 & İspanya & Domates & PVY-0 & 98 \\
\hline & & & & K16.94 & AJ303094 & Tunus & Biber & PVY-1 & 96 \\
\hline & & & & $\mathrm{Si}-15$ & AJ303093 & İtalya & Biber & PVY-1 & 96 \\
\hline & & & & PRI-509 & EU563512 & Hollanda & Patates & $\mathrm{PVY}^{\mathrm{C}}$ & 96 \\
\hline & & & & YC Zb & JF804785 & Polonya & Patates & $\mathrm{PVY}^{\mathrm{C}}$ & 96 \\
\hline & & & & SON-41 & AJ439544 & Fransa & S. nigrum & PVY-1,2 & 96 \\
\hline & & & & PVY-Kh81 & EF192311 & İran & Patates & $\mathrm{PVY}^{\mathrm{O}}$ & 93 \\
\hline & & & & SASA 207 & AJ584851 & UK & Patates & $\mathrm{PVY}^{\mathrm{N}}$ & 92 \\
\hline & & & & PB312 & EF026075 & $\mathrm{ABD}$ & Patates & $\mathrm{PVY}^{\mathrm{NTN}}$ & 90 \\
\hline & & & & Cou8/03 & JF804780 & Polonya & Patates & $\mathrm{PVY}^{\mathrm{NTN}}$ & 90 \\
\hline
\end{tabular}

\footnotetext{
*: Bu çalışmadaki biber izolatlarının, PVY genomundaki pozisyonlarının belirlenmesinde GenBank Kayıt Numarası NC_001616 olan PVY izolatının genomu esas alınmıştır. Bu izolatın kılıf protein bölgesi, 8573-9373 nükleotidleri arasında yer almaktadır.
} 


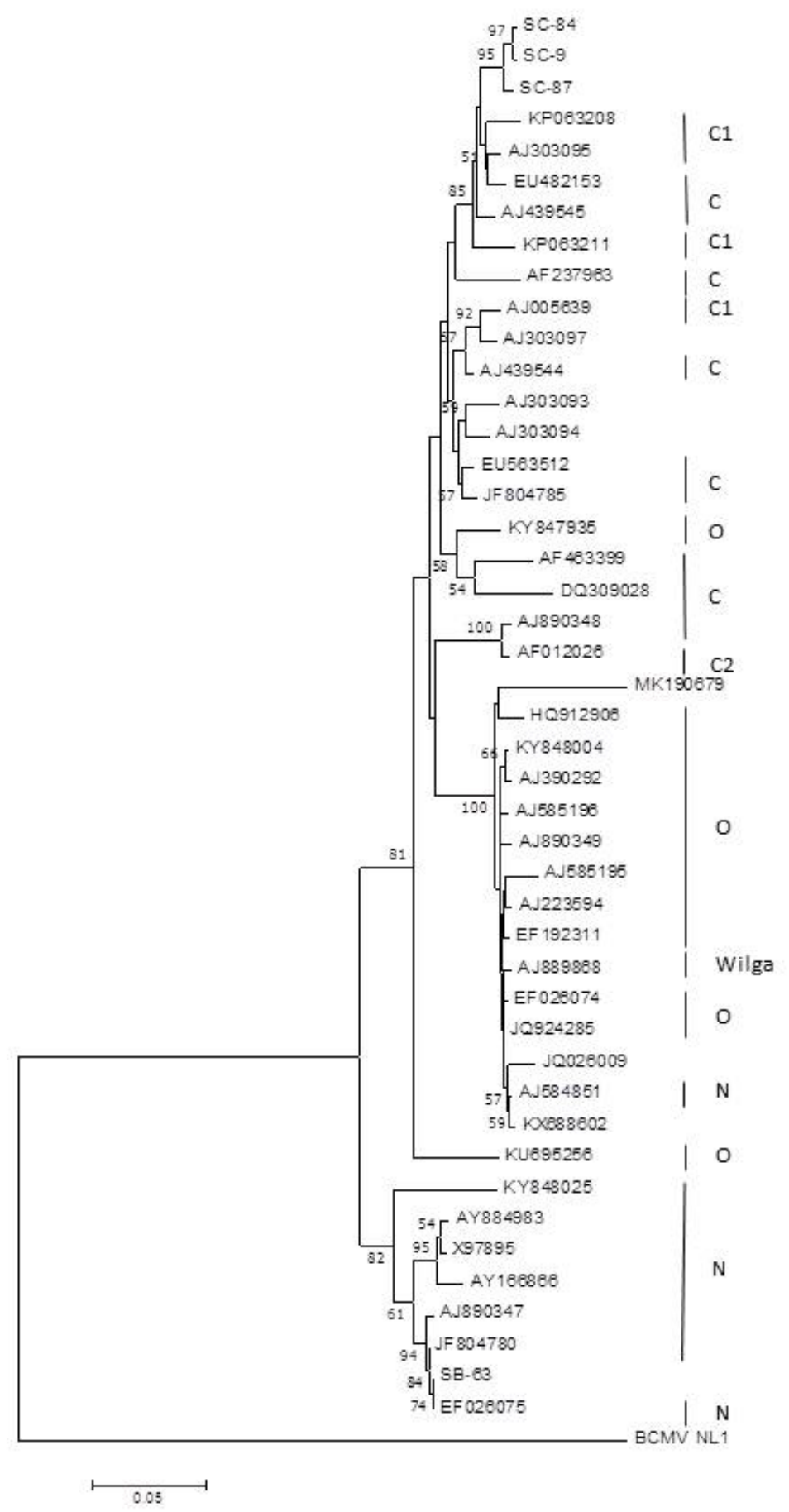

Şekil 3. Potato virus $Y$ (PVY) izolatlarının kılıf protein (CP) bölgesi nükleotit dizisine göre aralarındaki genetik ilişkiyi gösteren filogenetik ağaç. Filogenetik analizde MEGA 7 yazılımında yer alan Neighbor-joining (NJ) yöntemi kullanılmıştır. \% 50' nin altındaki bootstrap değerleri dendrogramda yer almamıştır. Ölçek, her nükleotid pozisyonu için 0.05 değişimi göstermektedir. Potyvirus cinsi üyesi Bean common mosaic virus NL1 1rk1 (KM023744), filogenetik ağacın oluşturulmasında dış grup olarak kullanılmıştır. Referans izolatlara ait bilgiler Çizelge 2'de yer almaktadır.

Figure 3. Phylogenetic tree showing genetic relationships among Potato virus $Y(P V Y)$ isolates according to the coat protein nucleotide sequences. The tree was constructed using Neighbor-Joining (NJ) method in the MEGA 7 program. Bootstrap values more than $50 \%$ are labelled. The scale bar represents 0.05 substitutions per nucleotide site. The sequence of Bean common mosaic virus (Potyvirus) NL-1 strain (KM023744) was used as the outgroup. The data of reference isolates are presented in Table 2. 

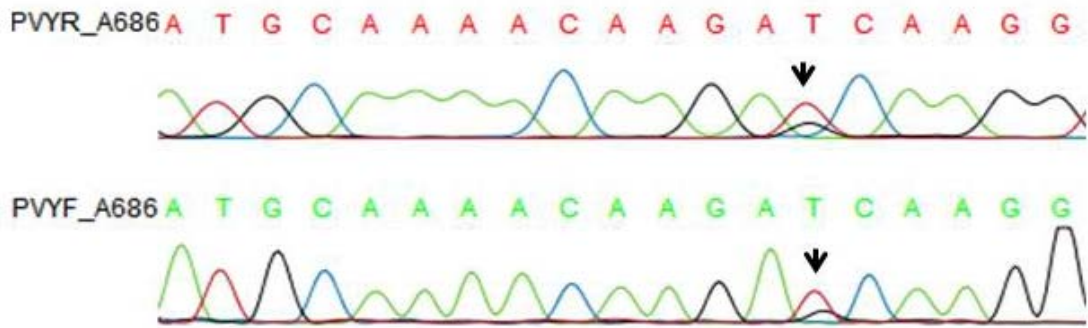

Şekil 4. SB-63 nolu izolatın CP gen bölgesinin her iki yöne ait primerler (ileri: PVYF ve geri: PVYR) ile elde edilen sekans sonucunun bir bölümü. Aynı pozisyondaki Timin veya Guanin pikleri hizalanmış dizide okla gösterilmiştir

Figure 4. The partial result of sequence analysis belonging to the CP region of the isolate SB-63 obtained with forward (PVYF) and reverse (PVY-R) primers. Thymine or guanine peaks at the same position of the sequence alignment are shown by arrow.

\section{Sonuç}

$\mathrm{Bu}$ çalışmada, Samsun ilinde biber üretim alanlarında PVY'nin 0 ve 1 patotiplerinin bulunduğu ortaya konulmuş, PVY-0 patotipinin PVY-1 patotipine göre daha yaygın olduğu belirlenmiştir. Her iki patotip de biber üretiminin yoğun olarak yapıldığ Bafra ilçelerinde tespit edilmiştir. Her ne kadar PVY-1 patotipi bölgede daha az oranda belirlenmiş olsa da, PVY-0 patotipine göre daha şiddetli belirtiler oluşturması nedeni ile bölgede yapılacak olan biber 1slahı çalışmalarında PVY-0 ve PVY-1 patotiplerinin her ikisine karşı dayanıklı çeşitlerin geliştirilmesine yönelik çalışmaların yapılması gerekmektedir. CP geni nükleotid dizi analizlerine göre PVY'nin SB-63 nolu izolatının diğer patotiplerden farklı bir profil sergilediği ortaya konmuştur. SB-63 izolatı ile ilgili daha detaylı çalışmaların yapılmasına ihtiyaç duyulmaktadır. Ayrıca bu çalışmada, Samsun ilinde PMMoV ilk defa belirlenmiştir. Bir Tobamovirus cinsi üyesi olan PMMoV, Türkiye'de bugüne kadar başta Akdeniz Bölgesi olmak üzere birçok bölgede tespit edilmiştir. Söz konusu virüsün Samsun ilinde biber üretim alanlarında ne derece yaygın olduğu, ekonomik anlamda zarara neden olup olmadığı bilinmemektedir. PMMoV'nin bölgede biber üretim alanlarındaki yaygınlığı ve epidemiyolojisi üzerine daha detaylı çalışmaların yapılması gerekmektedir.

\section{Teşekkür}

$\mathrm{Bu}$ araştırma, "Samsun ilinde biber üretim alanlarında enfeksiyon oluşturan Potato virus Y (PVY) patotiplerinin karakterizasyonu ve bazı biber çeşit ve hatlarının PVY'ye karşı dayanıklılık düzeylerinin araştırılması" isimli doktora tez çalışmasından üretilmiş ve Ondokuz Mayıs Üniversitesi PYO.ZRT1904.10.019 nolu Proje ile desteklenmiştir.

\section{Kaynaklar}

Abdalla O.A, Eraky A.I, Mohamed S.A, Fahmy F.G., 2016. Phylogenetic analysis of Potato virus Y (PVY) isolate from upper Egypt proves the widespread of PVY-NTN strain causing PTNRD disease in Egypt. Annals of Virology and Research, 2 (3): 1020.

Aramburu J, Galipienso L, Matas M., 2006. Characterization of potato isolates from tomato crops in northeast Spain. European Journal of Plant Pathology, 115: 247-258. DOI:10.1007/s10658-006-9003-X

Arl1-Sökmen, M., Mennan, H., Sevik, M.A., Ecevit, O., 2005. Occurrence of viruses in field- grown pepper crops and some of their reservoir weed hosts in Samsun, Turkey. $\begin{array}{llll}\text { Phytoparasitica, } & 33 & \text { (4): }\end{array}$ DOI:10.1007/BF02981301

Blanco-Urgoiti B., Sánchez, F., Pérez de San Román, C., Dopazo, J., Pons, F., 1998. Potato virus Y group C isolates are a homogenous pathotype but two different genetic strains. Journal of General Virology, 79: 2037-2042.

Buzkan, N., Demir, M., Öztekin, V., Mart, C., Çağlar, B. K., Y1lmaz., M. A., 2006. Evaluation of the status of capsicum viruses in the main growing regions of Turkey. EPPO 
Bulletin, $36 \quad(1): \quad 15-19 . \quad$ DOI:10.1111/J.13652338.2006.00936.X

Buzkan, N., Arpac1, B.B., Moury, B., Fabre, F., 2012. Sürekli virüs dayanıklılığı için Türkiye'de biberler ve potyvirüsler arasındaki genetik ilişkinin analizi. TÜBİTAK TOVAG 1090447 Nolu Proje Sonuç Raporu, 54s. http:// https://app.trdizin.gov.tr/publication/project/detail/TVRF MU16QXc (Erişim tarihi: 15.06.2020).

Buzkan, N., Arpacı, B.B., Görsoy, G., Zencirkıran, M., Moury, B., 2015. Genetic variability of Potato virus Y (PVY) and Tobacco etch virus (TEV) from naturally infected pepper fields in the Hatay region of Turkey. Archives of Phytopathology and Plant Protection. 48 (7): 588-600. DOI:10.1080/03235408.2015.1091133

Caranta, C., Thabuis, A., Palloix, A., 1999. Development of a CAPS marker for the Pvr4 locus: a tool for pyramiding Potyvirus resistance genes in pepper. Genome / National Research Council Canada. 42(6): 1111-1116. DOI:10.1139/G99-069

Chikh Ali M., Maoka T., Natsuaki T., Natsuaki K. T., 2010. PVYNTN-NW, a novel recombinant strain of Potato virus Y predominating in potato fields in Syria. Plant Pathology, 59: 31 - 41. DOI:10.1111/J.1365-3059.2009.02174.X

Clark, M.F., Adams, A.N., 1977. Characteristics of microplate metod of Enzyme-linked Immunosorbent Assay for the detection of plant viruses. Journal of General Virology, 34, 475-483. DOI:10.1099/0022-1317-34-3-475

Çelik, N., Özalp, R., Göçmen, M., 2012. Antalya ili örtü altı biber yetiştiriciliğinde Patates $\mathrm{Y}$ Virüsü (PVY) patotiplerinin belirlenmesi ve bazı biber çeşitlerinin PVY'ye karşı reaksiyonları. Bitki Koruma Bülteni, 52 (3): 235-246. DOI:10.16955/BKB.12862

Echer, M., Costa, C.P., 2002. Reaction of sweet pepper to the Potato Virus Y (PVYm)1. Scientia Agricola, 59 (2): 309314. DOI:10.1590/s0103-90162002000200016

FAO, 2020. Food and Agriculture Organization of the United Nations. Www.fao.org. URL: http://www.fao.org/faostat/en/\#data/QV. (Erişim tarihi:16.06.2020).

Felsenstein, J., 1981. Evolutionary trees from DNA sequences: a maximum likelihood approach. Journal of Molecular Evolution, 17 (6): 368-376. DOI:10.1007/BF01734359

Gebre-Selassie, K., Marchoux, G., Delecolle, B., Pochard, E., 1985. Variabilite naturelle des souches du virus Y de la porn me de terre dans les cultures de piment du Sud- Est de la France. Caracterisation et classification en pathotypes. Agronomie, 5 (7): 621-630. DOI:10.1051/agro:19850708

Glais,, L., Tribodet, M., Kerlan, C., 2002. Genomic variability in Potato potyvirus Y (PVY): evidence that PVYNW and PVYNTN variants are single to multiple recombinants between PVYO and PVYN isolates. Archives of Virology, 147, 363-378. DOI:10.1007/s705-002-8325-0

Grzela, R., Szolajska, E., Ebel, C., Madern, D., Favier, A., Wojtal, I., Zagorski, W., Chroboczek, J., 2008. Virulence factor of Potato virus $\mathrm{Y}$, genome-attached terminal protein VPg, is a highly disordered protein. Journal of Biological Chemistry, 283(1):
DOI:10.1074/JBC.M705666200

Gugerli, P., Fries, P., 1983. Characterization of monoclonal antibodies to Potato virus $\mathrm{Y}$ and their use for virus detection, Journal of General Virology, 64: 2471-2477. DOI:10.1099/0022-1317-64-11-2471
Hamalainen, J.H., Watanabe, K.N., Valkonen, J.P.T., Arihara, A., Plaisted, R.L., Pehu, E., Miller, L., Slack, S.A., 1997. Mapping and marker-assisted selection for a gene for extreme resistance to Potato virus Y. Theoretical and Applied Genetics, 94: 192-197. DOI:10.1007/s001220050399

Heldak, J., 1997. Symptomatological and serological evaluation of Potato virus Y (PVY) isolates in relation to potato tuber necrosic ringspot disease. Agriculture (Pol'nohospodárstvo), 43 (1): 18-32.

Jordan, R. L., Hammond, J., 1991. Comparison and differentiation of Potyvirus isolates and identification of strain-, virus-, subgroup- specific, and Potyvirus groupcommon epitopes using monoclonal antibodies. Journal of General. Virology, 72: 25-36. DOI:10.1099/0022-131772-1-25

Karasev A. V., Gray S. M., 2013. Continuous and emerging challenges of Potato virus Y in potato. Annual Review of Phytopathology, 51: 571-586. DOI:10.1146/annurevphyto-082712-102332

Kazinczi, G., Kovács, J., Takács, A.P., Horváth, J., Gáborjányi. R., 2003. Susceptibility of Capsicum breeding lines to NTN strain of Potato virus Y (PVY(NTN)) and Obuda pepper virus (ObPV). Communications in Agricultural and Applied Biological Sciences, 68: 555559.

Kerlan, C., 2006. Potato Virus Y. AAB Descriptions of Plants Viruses, 414.

Kerlan, C., Moury, B., 2008. Potato Virus Y. In Encyclopedia of Virology, 287-296. Edited by B.W.J. Mahy \& M.H.V. van Regenmortel. Oxford: Academic Press.

Kimura, M., 1980. A simple method for estimating evolutionary rates of base substitutions through comparative studies of nucleotide sequences. Journal of Molecular Evolution, $16(2)$ : 111-120. DOI:10.1007/BF01731581

Llave, C., Martinez, B., Diaz-Ruiz, J.R., López-Abella, D., 1999. Serological analysis and coat protein sequence determination of Potato virus Y (PVY) pepper pathotypes and differentiation from other PVY strains. European Journal of Plant Pathology, 105 (9): 847-857. DOI:10.1023/A:1008775910680

Moury, B., Morel, C., Johansen, E., Jacquemond, M., 2002. Evidence for diversifying selection in Potato virus $\mathrm{Y}$ and in the coat protein of other potyviruses. Journal of General Virology, 83: 2563-2573. DOI:10.1099/0022-1317-83-102563

Ogawa, T., Tomitaka, Y., Nakagawa, A., Ohshima, K., 2008. Genetic structure of a population of Potato virus $\mathrm{Y}$ inducing potato tuber necrotic ringspot disease in Japan; comparison with North American and European populations. Virus Research, 131: 199-212. DOI:10.1016/J.VIRUSRES.2007.09.010

Palloix, A., Abak, K., Gognalons, P., Daubeze, A.M., Güldür, M.E., Memouchi, G., Selassie, K.G., 1994. Virus diseases işnfecting pepper crops in Türkiye. 9th Congress of the Mediteranean Phytopathological Union, September 18-24, Kuşadası-Aydın, Türkiye, 469-472.

Palloix A., Kyle M., 1995. Proposal revision of gene nomenclature for Potyvirus resistance genes in Capsicum sp.. Capsicum and Eggplant Newsletter, 14: 26-29.

Quenouille J., Vassilakos N., Moury B., 2013. Potato virus Y: a major crop pathogen that has provided major insights 
into the evolution of viral pathogenicity. Molecular Plant Pathology, 14: 439 - 452. DOI:10.1111/mpp.12024

Revers, F., Le Gall, O., Candresse, T., Le Romancer, M., Dunez, J., 1996. Frequent occurrence of recombinant Potyvirus isolates. Journal of General Virology, 77: 19531965. DOI:10.1099/0022-1317-77-8-1953

Riechmann, J.L., Lain, S., Garcia, J.A., 1992. Highlights and prospects of Potyvirus molecular biology. Journal of General Virology, 73: 1-16.

Rigotti, S., Gugerli, P., 2007. Rapid identification of Potato virus Y strains by one-step triplex RT-PCR. Journal of Virological Methods, 140: 90-94. DOI:10.1016/J.JVIROMET.2006.11.002

Saitou, N., Nei, M., 1987. The neighbor-joining method: A new method for reconstructing phylogenetic trees. Molecular Biology and Evolution, 4: 406-425. DOI:10.1093/oxfordjournals.molbev.a040454

Soto, M.J, Luis Artega, M., Fereres, A., Ponz, F., 1994. Limited degree of serological variability in pepper strains of Potato virus $\mathrm{Y}$ as revealed by analysis with monoclonal antibodies. Annals of Applied Biology, 124: 37-43. DOI:10.1111/j.1744-7348.1994.tb04113.x

Thompson J.D, Higgins, D.G., Gibson, T.J. 1994. CLUSTALW: improving the sensitivity of progressive multiple sequence alignment through sequence weighting, position-specific gap penalties and weight matrix choice. Nucleic Acids Research. 22: 4673-4680. DOI:10.1093/nar/22.22.4673

TUİK, 2018. Türkiye İstatistik Kurumu. www.tuik.gov.tr. URL: https://biruni.tuik.gov.tr/medas/?kn=92\&locale=tr (Erişim tarihi:16.06.2020).

Urcuqui-Inchima, S., Haenni, A.L., Bernardi, F., 2001. Potyvirus proteins: a wealth of functions. Virus Research, 74: 157-175. DOI:10.1016/S0168-1702(01)00220-9

Van der Vlugt, R.A, Leunissen, J., Goldbach, R., 1993. Taxonomic relationships between distinct potat virus $\mathrm{Y}$ isolates based on detailed comparisons of the viral coat proteins and 3'-nontranslated regions. Archives of Virology, 131 (3-4): 361-375. DOI:10.1007/BF01378638

Varveri, C., 2000. Potato Y potyvirus detection by immunological and molecular techniques in plants and aphids. $\quad$ Phytoparasitica, 28: 141-148. DOI:10.1007/BF02981743 